\title{
Assessment instrument for practicum skills in Trimyristin separation for undergraduate students
}

\author{
Naseer Ahmed ${ }^{1 *}$, Senam Senam ${ }^{2}$, Antuni Wiyarsi ${ }^{2}$ \\ University of Haripur. Hattar Road Near Swat Chowk Haripur, Khyber Pakhtunkhwa, Pakistan \\ ${ }^{2}$ Universitas Negeri Yogyakarta. Jalan Colombo No. 1, Karangmalang, Yogyakarta 55281, Indonesia \\ * Corresponding Author email: naseerahmed1992@gmail.com
}

Received: 15 August 2018; Revised: 28 February 2019; Accepted: 12 March 2019

\begin{abstract}
Assessment of practicum plays an essential role in gaining knowledge and skill. Because practical work is an essential component of science courses, there were need to develop new instruments to examine practicum skill. To gain the purpose, Research and Development method used, Borg and Gall's model was adopted in this research. Observation sheets were used to obtain data. The qualitative data analysis technique was used to make coding. The data were described using descriptive statistics. It was used to determine the ability of students to practice in general, purposive sampling technique used for data collection. Products of practical's skills assessment contain four aspects, fifteen indicators, and four criteria. The product was validated by two expert judges, shortcomings, and grammatical mistakes were revised. In the separation of Trimyristin, mostly student practicum skill was "good" while few students' skills were "very good" and few other students earned "sufficient" none of them got "poor" and "very poor". In each aspect of practicum skills "very good" in drawing, experimental and observations skills were "good" while reporting and interpretive skills were "sufficient". For further dissemination, the reliability test can be done by using inter-rater reliability test to make the product more efficient and applicable.
\end{abstract}

Keywords: assessment, practicum skill, organic chemistry, Trimyristin

How to Cite: Ahmed, N., Senam, S., \& Wiyarsi, A. (2019). Assessment instrument for practicum skills in Trimyristin separation for undergraduate students. Jurnal Inovasi Pendidikan IPA, 5(1), 89-97. doi:https://doi.org/10.21831/jipi.v5i1.24515

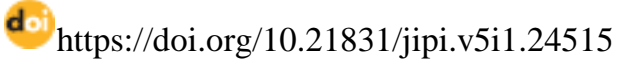

\section{INTRODUCTION}

The assessment has a leading role in chemistry learning. Assessment can be used as a means of selection as a way of diagnosing strengths and weaknesses. The most important is judging performance in education and training and qualification maybe awarded [Scottish Vocational Council (Windeatt, Hardisty, \& Eastment, 2000). As chemistry is an experimental science, so laboratory is a central part of chemistry. A laboratory is a place where experiment can be performed, and laboratory occupies a central role in a curriculum of chemistry in comprehensive universities. Teachers have to understand the way of using authentic and practical assessment in chemistry learning. Teachers have to know what students learn more in practical work and what they need more to know and how they can perform well in final examinations in the practical lab (Hofstein \& Lunetta, 2004). Whether they understand well or not about practical work and way of doing
Experimental practical work provided a robust framework and way for the development and assessment of practicum skills of student's. To assess these phases, validities, reliable and usable measure must be developed and implemented.

Wright (2011) have explained two models of student-centered learning in music education department: one is Comprehensive Musicianship through Performance (CMP) in which, after choosing a piece of instrument which have to be learned, the student investigates everything by himself to know about that piece how to use it in playing and what's its leading role in instrument, adding to the knowledge of both students and teachers; in another, Arts PROPEL, students are taught by teacher's step by step toward higherlevel of learning as they interact metacognitively with the course content. Baxter \& Gray (2001) explained that for effective learning, it is necessary to choose such a model in which students can actively engage and can do the learning process. The teacher can expect that student has 
to be an active learner that there will be no more passive learner who absorbs information and learning passively, and teacher needs to facilitate all the role that he can give for active learning it will be a positive effect in the learning process (Materu, 2007).

A teaching method is how to deliver knowledge either in a class or outside the class, such as a laboratory. An oral presentation as one of the teaching methods plays a significant role in teaching, and it is one of the best methods. Evidence from some disciplines suggests that oral presentations to large groups of passive students contribute very little to real learning. In physic, mostly teachers not help students to give profound concept in fundamental physics like in electricity and in mechanics (Koponen \& Huttunen, 2013). Moreover, also student grades in a large general chemistry lecture course cannot correlate with the lecturing skills and experience of the instructor (Gottfried, 2009). Another good teaching method was a class discussion when lecturer chose techniques how to engage students in the learning process for this they initiate short student discussions individually to attain desire learning process (King, 2016). Encouraging the students to have class discussion can be a way to keep students engaged in the teaching and learning process. Moreover, there are several ways to help students make the transition from passive listeners to active participants in their learning (Wilke, 2003).

Initially, as (Debarnot et al., 2009) has observed, that science educators think that laboratory work is just the development of the mind that the laboratory became the central focus of chemistry and science instruction'. In practice, while in England, laboratory activities just restricted to confirmatory exercises of elements and formal observational tasks, during the early part of the twentieth century, the formal nature of these laboratory activities become the cause of declining of enrolment in universities because of its restriction (Materu, 2007). Mostly laboratory exercises do not offer new things to students. Mostly, teachers discuss a phenomenon in a classroom by his lecture or presentation and give instruction how to perform and then leave on students to verify in the laboratory what has been stated earlier in a class by teacher instruction. There must be some useful method that laboratory work can proceed rather than follows the classroom discussion of a topic or principle which causes much error in calculations in many chemistry classes (McComas, 2008). In the teacher training program, a classroom observation is a valuable tool to assess the performance of candidates mostly focus on cognitive, attitude and conative values of candidates (Lasagabaster $\&$ Sierra, 2011).

Teachers look at the results of schooling every day in their classrooms. Observe students products, observe working in groups and know a child's capacities of performing giving a task, information that can be gathered from such classroom-based observations is very valuable for improving students skills. Observation and assessment processes can be used to identify the effectiveness of specific activities, and the practice in the lab after observation of student's activities teacher can give reward according to student's performance. In an extensive research universities laboratory courses are typically taught by a graduate teaching assistant who plays a vital role in quality undergraduate education and the students can get the point quickly and perform well (Kendall \& Schussler, 2013). The assessment shows students level and helps in teaching method which method can be adapted to learn more and, as Pain et al. (2007) observe, actually drives their learning. Assessment has many functions like Shlonsky \& Gibbs (2004) states that assessment has 6 main functions like capturing student time and attention, generating appropriate student learning activity, providing timely feedback which students pay attention to, helping students to internalize the discipline's standards and notions of equality, creating levels whether they are passed or fail it will help to standardize course more.

After understanding, students have a clear concept about their lesson, in many countries teachers spent much time in supervising chemical laboratory work but the bulk of science assessment is traditionally non-practical in nature (Nedungadi \& Raman, 2011). If there is a discussion of instruments, assessment instruments can be used to an achievement test to assess cognitive outcomes, an attitude survey to assess affective outcomes, and manipulative skills observation checklist to assess psychomotor outcomes. The learning of chemistry aims to get the understanding of the chemical facts and concepts, the capability of knowing and solving problems in-depth, the skills to experiment in the laboratory as well as to have the scientific attitude which can be developed in daily life. Based on the goals, so clearly the chemistry learning does not only develop the cognitive competency merely but also includes the attitude competency 


\section{Jurnal Inovasi Pendidikan IPA, 5 (1), 2019 - 91}

Naseer Ahmed, Senam Senam, Antuni Wiyarsi

and psychomotor development. Moreover, here is a discussion of the assessment of practicum that the teacher wants to know how many students learn during the course and how is students' performance in a test or experiment in the laboratory.

Chemistry laboratory can be a valuable learning environment only when the instructor understands the purpose of the laboratory experience well and must know how to teach others and which method applies, a way of explanation etc. The past several studies have reported that teachers do not utilise laboratories for many reasons, there are many reasons but mainly because of lack of knowledge and laboratory skills (Tatli \& Ayas, 2012). The laboratory allows students to observe chemical systems and all the chemical reactions going on in laboratory and to get data on the base of experiment and developed principles discussed in the textbook in class (Silagy \& Haines, 2001). Practical can perform well if undergraduate students and teachers know the purpose of the laboratory and purpose of experience in laboratory and know the accurate method of the experiment as well according to (Cooper, Robinson, \& Patall, 2006). Recent test results showed that the efficacy of technical skill approaches how is it necessary, which is paid attention throughout laboratory applications.

Laboratory works in chemistry help students to learn necessary practicum skills and in the sense categories of domains learning might suggest that organic chemistry undergraduate students' opinions that laboratory practices were mostly concentrated on the cognitive domain. After that, they focused on effective and more least on psychomotor domains. Organic chemistry undergraduate students mostly cognitively centred they do not pay more attention to psychomotor approach that's why organic chemistry undergraduate students do not give attention to laboratory work and practicum skills as well (Zakaria, Latip, \& Tantayanon, 2012). Student's competence to undertake any science learning activity in which they are involved in manipulating, discussing and observing real objects and materials from theories which are read in books (Abrahams \& Reiss, 2012).

Assessment of practicum skills enables students to explain transparently not only their understanding of how practical work need an arrangement. It should be undertaken in terms of design, collection of results and evaluation of the practical but also their competency in using their practicum skills. Apparatus handling skills towards an approach that sees its role primarily for the development and enhancement of knowledge and understanding of most important concepts that can be assessed adequately. Reliably, it depends on quite acceptable instruments with high validity and reliability with all aspects that are needed during practical and observer can observe undergraduate students practicum skills in the organic laboratory with accuracy. Assessing practicum skills is very important in making sure that students got all the needed practicum skills or not. Assessment not only measures the effects of learning of individual students but also the sum of a student of class or community experiences defined in a meaningful system of performance indicators. Assessment in practical plays an essential role for gaining much knowledge and skills, although practical work is an essential component of science courses $\mathrm{n}$ many countries teachers spent considerable much time in supervising chemical laboratory work the bulk of science assessment is traditionally nonpractical in nature (Nedungadi \& Raman, 2011).

There was a persistent suspicion among examiners about the reliability of the results of practical assessment, Reluctance on the part of the examiners to make the weighting of the practical work 'too large' even though it was considered significant (Harden \& Cairncross, 2006). Organic chemistry undergraduate students who got training mostly do not know how to perform practical work, but after getting the training, they become skilful and can transfer their knowledge to students. Practical is like the backbone of science, and in many cases, it is considered as successful, especially when the participants understand the objectives and purpose of the teaching. What are the aims of teaching and what is the importance of practical chemistry for undergraduates is essential to improve their basic skills in performing the practical, correct measurement, analyse data and write the best report? Microscale approach can be used to solve the problem in improving the quality of organic chemistry (Zakaria et al., 2012). Students sometimes hesitate to work in the organic lab as they mostly listen from another lab that it is dangerous because of the hazardous nature of organic chemicals; some students feel difficulty to complete the test. Some students after feeling little difficulties perform well, and they enjoyed much organic chemistry practical, sometimes they enjoy more practical than course worked they get higher grades in the lab than in 
lecture (Ryan, 2001). Practical is like the backbone of science, and in many cases, it is considered as successful, especially when the participants understand the objectives and purpose of the teaching. What are the aims of teaching, and what are the importance of practicum and how to get skills in practicum skills? How to get skills in practicum skills (Nivalainen, Asikainen, Sormunen, \& Hirvonen, 2010).

Laboratory equipment is necessary to practice organic chemistry. With a fully equipped laboratory, students can perform well in the experiment. The first step must be for laboratory familiarization; the second step must know the location of glassware and instruments in the laboratory. Everything must be clean. Everybody must be responsible for cleaning after doing experiments as there are some sensitive instruments like IR needs to be clean after the experiment. Students must keep safety measures; there are big chances of accident students must use instruments carefully, each student is assigned a set of two drawers and a cabinet containing various glassware and apparatus that will be used during laboratory experiments. Students must be familiar with lab drawer; organic chemistry is a science of extraction and science of synthesis. Students must be familiar with the correct use of instruments (Sloop et al., 2012).

According to Akcay, Feyzioglu, \& Tuysuz (2003), practical work in laboratory improves students' science process, problem-solving skills, practicum skills, innovative thinking and to enhance their interests, attitudes behaviour towards scientific approaches. Lock (1989) suggest using a questionnaire as an instrument to check practicum skills. Got a result that the correlations between observation kills, manipulation and reporting skills and examination grades were all shown from average low, the suggestion was given that have little predictive value. According to Okebukola, Owolabi, \& Okebukola (2013) study on the acquisition of practicum skills and abilities are a major goal of laboratory work. An interesting result was found in this study that studies focused on competitive group outperformed to measure cooperative and individualism groups. First, the students in the competitive group were able to judge and formulate problems, design of research and control, make a report and then report measurements. Master of one skill affects the development of other skills in practical; it's necessary to move from easy to hard skills (Kong, Chia, Goh, Chia, \& Brouillard,
2003). Description of observations that obtain from the study, interpretation of observed data, determine and locate the accuracy of experimental data accurately, explain the conclusions, and take results and prediction based on obtained results and differentiate which group of students perform well and which group students did not perform well.

There were no such instruments which can measure practical skills when the separation of trimyristin from nutmeg happen, and they need some specific aspects, indicators and criteria. Regarding all those problems, there was a need to developing new instruments which have specific aspects, indicators and criteria that have to use during the separation of trimyristin from nutmeg, can assess all required practical skills. In this research, new instruments developed which can assess practicum skills of undergraduate students.

\section{METHOD}

This research was conducted at the Universitas Negeri Yogyakarta. R\&D method was used in this research the model of Borg \& Gall (1983) was adopted. This research is undertaken

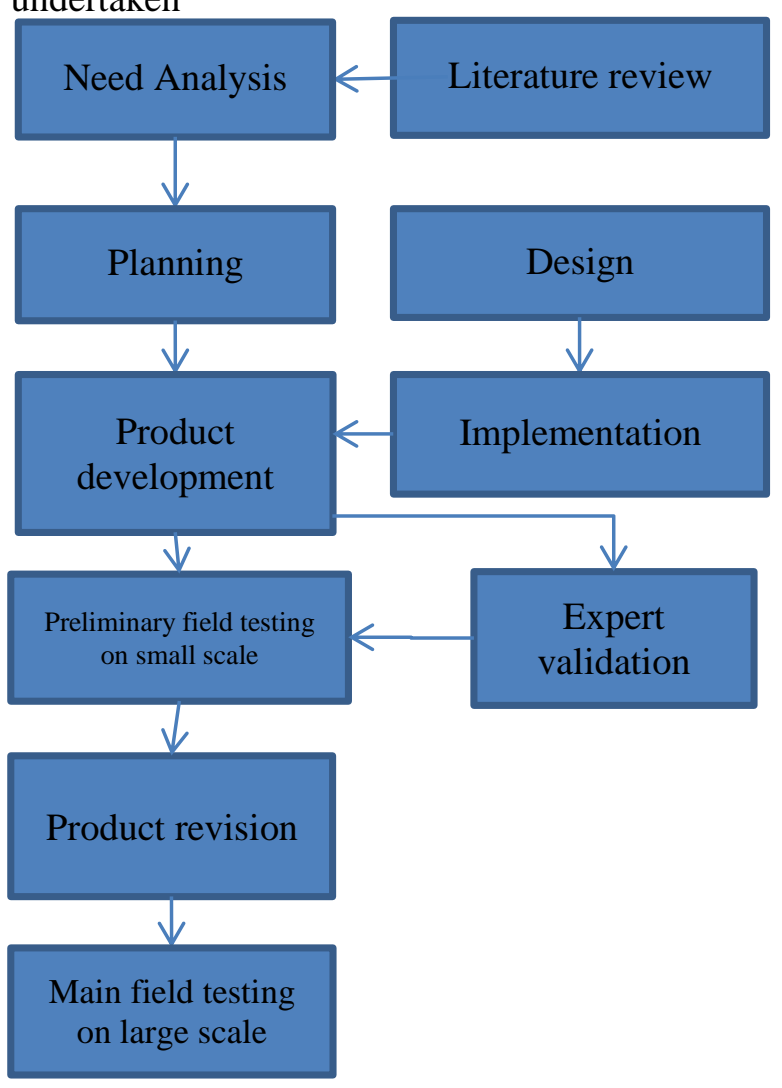

Figure 1. Research procedure adopted from Borg \& Gall scheme

To assess organic chemistry undergraduate students experimental skills and to develop one 
unique product to assess practicum skills of organic chemistry undergraduate students. The subject is students of undergraduate organic chemistry. Product is tested on two scales. A small scale is used to examine the quality of the product, large scale to the implementation of developed performance assessment instruments. The subject research at small scale test amounted 30 students, the subject research at extensive scale test amounted 75 students.

As this research used Borg \& Gall (1983) step one involves research and information collecting or need analysis, which is including a review of the previous literature and studies, Step two and three which consist of the product planning and development of a preliminary form of the product. Planning includes skills, stating objectives determining course sequence; development of a preliminary form of product includes the preparation of instructional materials, and evaluating devices or measuring skills about practicum skills then preceded validation by two experts. Step four involved preliminary product testing on a low scale; it will be tested in an organic chemistry laboratory. In step 5, there was a revision of the product after tested in low scale and six main fields testing here was the implementation of the product on a large scale in a large number of students.

Table 1. Profile of Practicum Skills Quality Categories

\begin{tabular}{rll}
\hline No. & \multicolumn{1}{c}{ Score Range (i) } & \multicolumn{1}{c}{ category } \\
\hline 1. & $\overline{\mathrm{X}}>\mathrm{Mi}+1,5 \mathrm{SBi}$ & Very Good (VG) \\
2. & $\mathrm{Mi}+0,5 \mathrm{SBi}<\overline{\mathrm{X}} \leq \mathrm{Mi}+1,5$ & Good (G) \\
& $\mathrm{SBi}$ \\
3. & $\mathrm{Mi}-0,5 \mathrm{SBi}<\overline{\mathrm{X}} \leq \mathrm{Mi}+0,5$ & Sufficient (S) \\
& $\mathrm{SBi}$ & \\
4. & $\mathrm{Mi}-1,5 \mathrm{SBi}<\overline{\mathrm{X}} \leq \mathrm{Mi}-0,5$ & Poor (P) \\
& $\mathrm{SBi}$ & \\
5. & $\overline{\mathrm{X}} \leq \mathrm{Mi}-1,5 \mathrm{Sbi}$ & Very Poor (VP) \\
\hline
\end{tabular}

Observation sheet was used to collect data while sampling technique was purposive sampling technique. The qualitative data analysis technique that was carried out in this research is to make the coding of suggestions given by experts, and then the coding has used to revise the instruments. Descriptive analysis is also used to determine the ability of students to practice in general. The test that has done is to look for the average score then viewed based on the score interval in the specified category. Practical ability category can be seen based on what was stated by (Azwar, 2010) regarding the score interval as follow by Table 1 .

\section{RESULTS AND DISCUSSION}

Obtain product has four aspects, which are experimental and manipulative skills, observational skills, drawing skills and reporting and interpretive skills 15 indicators and four criteria sample is given in Table 2 .

Instrument considered valid if the result means score by expert judgments achieve, according to experts the concept of assessment was suitable, indicators were suitable and can use for assessments of student's practicum skills, and there is little improvements need which are given in Table 3, which was revised, and revision can be seen in Table 4.

Small-scale test conducted to determine deficiencies and legibility or the instruments. The subject of the small-scale test was 30 students from undergraduate organic chemistry class. Undergraduate students perform practical of separation of trimyristin from nutmeg seed and observers give suggestions about the product according to the observers. Statements must increase from 15 to 18 because there is need of some extra steps in practical. Choice of chemical was wrong in instruments it was dichloromethane written in instruments it was replaced by hexane. This practical also has some extra points like to get raw material there was need of crushing of seeds it also needed to observe so from observer it was suggested to add statements about other steps also which are part of this experiment.

Organic chemistry student's practicum skills during performance separation of Trimyristin from nutmeg seed, the Figure 2 shows that a considerable number of students have "good" category practicum skills during performing separation of Trimyristin from nutmeg seeds which gives a total of $71 \%$ (red). While some students found on high skills during performing practical got "very good" category which can be seen in table 3 with a total of $25 \%$ (dark blue). Few students' practicum skills were just on "sufficient" category with a total of $4 \%$ (green). No students got "poor" (purple) and 'very poor" (light blue) category practicum skills, during performing separation of Trimyristin from nutmeg seeds. Details can be seen in Figure 2. 


\section{Jurnal Inovasi Pendidikan IPA, 5 (1), 2019 - 94}

Naseer Ahmed, Senam Senam, Antuni Wiyarsi

Table 2. Criteria to Assess Practicum Skill

\begin{tabular}{lllc}
\hline Aspects & Indicators & Criteria & Score \\
\hline Exp. and & Use the apparatus for Isolation of & UgS can set extractor & 4 \\
Manip. $^{1}$ skills & Trimyristin from nutmeg in a proper way & Soxhlet with sequence and use \\
& & according to instructions. & \\
& & UgS are unable to set extractor & 3 \\
& Soxhlet with the sequence but use & according to instructions. \\
& UgS can set extractor & 2 \\
& Soxhlet with the sequence but cannot & \\
& use according to instructions. & UgS are unable to set extractor \\
& Soxhlet with sequence and cannot use & according to instructions. \\
\hline
\end{tabular}

Table 3. Experts' Judgment about Product

\begin{tabular}{|c|c|c|}
\hline Language & Structure & Concept \\
\hline $\begin{array}{l}\text { There were many spelling mistakes and } \\
\text { unclear language mentioned by the first } \\
\text { expert like "undergraduate students } \\
\text { didn't put sample inside soxhlet } \\
\text { apparatus and observe the reaction } \\
\text { "here was grammatically many } \\
\text { mistakes, corrected statement have to } \\
\text { be like this "undergraduate students } \\
\text { doesn't put sample inside soxhlet } \\
\text { apparatus and observe the reaction } \\
\text { carefully" these mistakes revised. }\end{array}$ & $\begin{array}{l}\text { In the Structure part there were some } \\
\text { statements need to be revised and } \\
\text { modified like For observing there was } \\
\text { one statement "undergraduate students' } \\
\text { calibrates balance and weights } \\
\text { chemicals inaccurate amount" but } \\
\text { actually it's totally against chemistry } \\
\text { instructions of practical because mostly } \\
\text { chemical weight by lab attended or } \\
\text { chemistry teacher, term was revised } \\
\text { and fitted right statement. }\end{array}$ & $\begin{array}{l}\text { The Concept of } \\
\text { assessment was suitable; } \\
\text { indicators were suitable } \\
\text { and can use for } \\
\text { assessments of students } \\
\text { practicum skills. Only } \\
\text { item number } 6 \text { and seven } \\
\text { slightly modified, which } \\
\text { was modified by the } \\
\text { researcher later. }\end{array}$ \\
\hline
\end{tabular}

Table 4. Summary of Revision Developing Performance Assessment Instrument

\begin{tabular}{ccl}
\hline No. & Instrument & \multicolumn{1}{c}{ Improvement Notes } \\
\hline 1. & Outlines & $\begin{array}{l}\text { Noticed at communication skills and collaboration skills whether including } \\
\text { observation skills or no }\end{array}$ \\
2. & Rubrics & $\begin{array}{l}\text { Clarified statements in rubrics, correct spelling mistakes, structure, item number } 6 \\
\text { and seven slightly modified, which was modified by the researcher. } \\
\text { Specify the title on the observation sheet }\end{array}$ \\
3. $\begin{array}{l}\text { Observation } \\
\text { sheet }\end{array}$ & \\
\hline
\end{tabular}

Practicum skills of organic chemistry undergraduate students in each aspect are given in Figure 3. Figure 3 shows that most students have good skills in all aspect during performing separation of Trimyristin from nutmeg seeds. In drawing skills (green) mostly students have "very good" category skills, but some students have "good" and "sufficient" category skills as well.

Observational skills (red) mostly student's skills were on a "good" category. Experimental and manipulation skills were also on the "good" category. Surprisingly, reporting and interpretative skills (purple) during performing separation of nutmeg were mostly "sufficient". Some students also have "poor", and some students have "very poor" skills, only some students have "good" category practicum skills, and some students have "very good" category practicum skills details are given Figure 3.

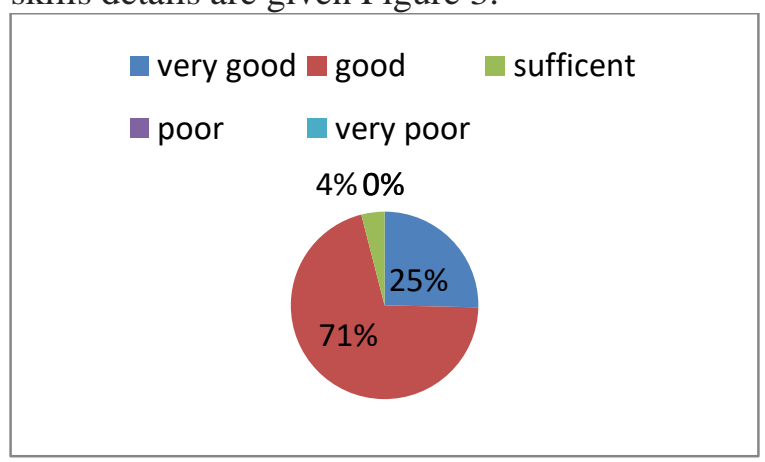

Figure 2. Practicum Skills of Students in the Separation of Trimyristin from Nutmeg

\footnotetext{
${ }^{1}$ Experimental and manipulative

${ }^{2}$ Undergraduate students
} 
Jurnal Inovasi Pendidikan IPA, 5 (1), 2019 - 95

Naseer Ahmed, Senam Senam, Antuni Wiyarsi

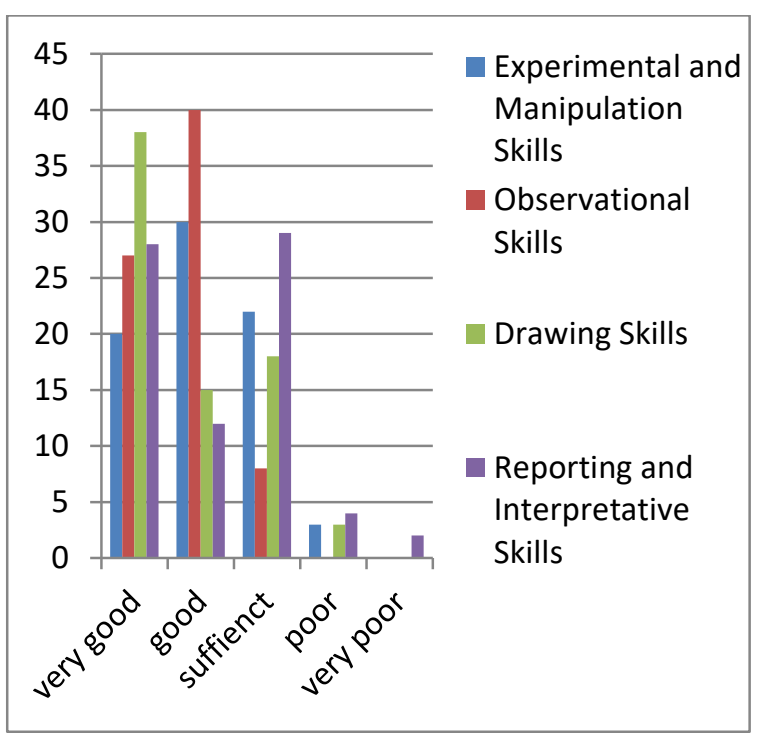

Figure 3. Practicum Skill of Students in each Aspect in the Separation of Trimyristin from Nutmeg Seed

\section{CONCLUSION}

This product is different from other product because this product is specific for four practical chromatography techniques, aldol condensation, separation of Trimyristin and synthesis of salicylic acid. This product is new innovations in assessing practicum skills in organic chemistry. In this product, all those aspects, indicators and criteria are chosen which were necessary for the assessment of practical skills which were not present in previous products, because of it is one of the unique product. There were four aspects used in the rubrics. The obtained product was highly validated and reliable. Mostly organic chemistry undergraduate students' performance was "very good" in the overall view, but some students have "good" and "sufficient" category skills as well. In the separation of Trimyristin from nutmeg seeds surprisingly high numbers of students' skills were "good" and only $25 \%$ students' skills were "very good", and very few organic chemistry undergraduate students' skills were "sufficient". In each aspect of practicum skills "very good" in drawing skills, experimental and manipulative and observations skills were "good" while reporting and interpretive skills were "sufficient."

\section{REFERENCES}

Abrahams, I., \& Reiss, M. J. (2012). Practical work: Its effectiveness in primary and secondary schools in England. Journal of Research in Science Teaching, 49(8), 1035-1055. https://doi.org/10.1002/tea.21036

Akçay, H., Feyzioğlu, B., \& Tüysüz, C. (2003). The effects of computer simulations on students' success and attitudes in teaching chemistry. Educational Sciences: Theory \& Practice, 3(1), 20-26.

Azwar, S. (2010). Pengantar psikologi inteligensi (16th ed.). Yogyakarta: Pustaka Pelajar.

Baxter, S., \& Gray, C. (2001). The Application of Student-Centred Learning Approaches to Clinical Education. International Journal of Language \& Communication Disorders, 36(s1), 396-400. https://doi.org/10.3109/136828201091779 18

Borg, W. R., \& Gall, M. D. (1983). Educational research: An introduction. New York: Longman.

Cooper, H., Robinson, J. C., \& Patall, E. A. (2006). Does homework improve academic achievement? A synthesis of research, 1987-2003. Review of Educational Research, 76(1), 1-62. https://doi.org/10.3102/003465430760010 01

Debarnot, U., Creveaux, T., Collet, C., Gemignani, A., Massarelli, R., Doyon, J., \& Guillot, A. (2009). Sleep-related improvements in motor learning following mental practice. Brain and Cognition, 69(2), 398-405. https://doi.org/10.1016/j.bandc.2008.08.0 29

Gottfried, H. (2009). Teaching and learning guide for: Gender and employment: A global lens on feminist analyses and theorizing of labor markets. Sociology Compass, 3(5), 853-860. https://doi.org/10.1111/j.17519020.2009.00234.x

Harden, R. M., \& Cairncross, R. G. (2006). Assessment of practical skills: The objective structured practical examination (OSPE). Studies in Higher Education, $5(2)$, 187-196. https://doi.org/10.1080/030750780123313 77216

Hofstein, A., \& Lunetta, V. N. (2004). The laboratory in science education: Foundations for the twenty-first century. Sci $\quad E d, \quad 88(1), \quad 28-54$. https://doi.org/10.1002/sce.10106 
Kendall, K. D., \& Schussler, E. E. (2013). Evolving impressions: undergraduate perceptions of graduate teaching assistants and faculty members over a semester. CBE-Life Sciences Education, 12(1), 92105. https://doi.org/10.1187/cbe.12-070110

King, S. O. (2016). Investigating the most neglected student learning domain in higher education: A case study on the impact of technology on student behaviour and emotions in university mathematics learning. Problems of Education in the 21st Century, 72, 31-52.

Kong, J.-M., Chia, L.-S., Goh, N.-K., Chia, T.-F., \& Brouillard, R. (2003). Analysis and biological activities of anthocyanins. Phytochemistry, 64(5), 923-933. https://doi.org/10.1016/S00319422(03)00438-2

Koponen, I. T., \& Huttunen, L. (2013). Concept development in learning physics: The case of electric current and voltage revisited. Science \& Education, 22(9), 2227-2254. https://doi.org/10.1007/s11191-012-9508$\mathrm{y}$

Lasagabaster, D., \& Sierra, J. M. (2011). Classroom observation: Desirable conditions established by teachers. European Journal of Teacher Education, 34(4), 449-463. https://doi.org/10.1080/02619768.2011.58 7113

Lock, R. (1989). Assessment of practical skills part 1. The relationships between component skills. Research in Science \& Technological Education, 7(2), 221-233. https://doi.org/10.1080/026351489007020 9

Materu, P. (2007). Higher education quality assurance in Sub-Saharan Africa. Washington D.C. https://doi.org/10.1596/978-0-8213-72722

McComas, W. F. (2008). Seeking historical examples to illustrate key aspects of the nature of science. Science \& Education, $17(2-3)$, 249-263. https://doi.org/10.1007/s11191-007-9081y

Nedungadi, P., \& Raman, R. (2011). Computer Assessment of Practical Skills (CAPS) using Scaffolding Methodology as Enabler of Learning. In IAJC-ASEE International Conference (Vol. 277, pp. 978-979).

Nivalainen, V., Asikainen, M. A., Sormunen, K., \& Hirvonen, P. E. (2010). Preservice and inservice teachers' challenges in the planning of practical work in physics. Journal of Science Teacher Education, 21(4), 393-409. https://doi.org/10.1007/s10972-010-9186Z

Okebukola, P. A., Owolabi, O., \& Okebukola, F. O. (2013). Mother tongue as default language of instruction in lower primary science classes: Tension between policy prescription and practice in Nigeria. Journal of Research in Science Teaching, 50(1), 62-81. https://doi.org/10.1002/tea.21070

Pain, D. J., Carter, I., Sainsbury, A. W., Shore, R. F., Eden, P., Taggart, M. A., ... Raab, A. (2007). Lead contamination and associated disease in captive and reintroduced red kites Milvus milvus in England. Science of The Total Environment, 376(1-3), 116127.

https://doi.org/10.1016/J.SCITOTENV.20 07.01 .062

Ryan, W. J. (2001). Comparison of student performance and attitude in a lecture class to student performance and attitude in a telecourse and a web-based class. Nova Southeastern University.

Shlonsky, A., \& Gibbs, L. (2004). Will the real evidence-based practice please stand up? Teaching the process of evidence-based practice to the helping professions. Brief Treatment and Crisis Intervention, 4(2), 137-153. https://doi.org/10.1093/brieftreatment/mhh011

Silagy, C., \& Haines, A. (2001). Evidence-based practice in primary care. (Chris Silagy, Ed.) (2nd ed.). London: BMJ Books.

Sloop, J., Pennington, R., Tsoi, M. Y., Paredes, J., Pursell, D., Coppock, P., \& Giles, G. (2012). Undergraduate organic chemistry I \& II laboratory manual. Georgia Gwinnett College.

Tatli, Z., \& Ayas, A. (2012). Virtual chemistry laboratory: Effect of constructivist learning environment. Turkish Online Journal of Distance Education, 13(1), 183-199. Retrieved from http://tojde.anadolu.edu.tr/makale_goster. 


\section{Jurnal Inovasi Pendidikan IPA, 5 (1), 2019 - 97}

Naseer Ahmed, Senam Senam, Antuni Wiyarsi

php?id $=740$

Wilke, R. R. (2003). The effect of active learning on student characteristics in a human physiology course for nonmajors. Advances in Physiology Education, 27(4), 207-223.

https://doi.org/10.1152/advan.00003.2002

Windeatt, S., Hardisty, D., \& Eastment, D. (2000). The internet. London: Oxford University Press.

Wright, G. B. (2011). Student-centered learning in higher education. International Journal of Teaching and Learning in Higher Education, 23(3), 92-97. Retrieved from http://www.isetl.org/ijtlhe/abstract.cfm?m id $=834$

Zakaria, Z., Latip, J., \& Tantayanon, S. (2012). Organic chemistry practices for undergraduates using a small lab kit. Procedia - Social and Behavioral Sciences, 59, 508-514. https://doi.org/10.1016/j.sbspro.2012.09.3 07 